\title{
THE INFLUENCE OF OWNER EDUCATION LEVELS, OWNER ACCOUNTING KNOWLEDGE, BUSINESS SCALE, AND BUSINESS AGE ON THE USE OF ACCOUNTING INFORMATION IN MSME'S IN WONOGIRI
}

\author{
Irvan Arie Hananto ${ }^{1)}$, Bambang Agus Pramuka ${ }^{2)}$, Icuk Rangga Bawono ${ }^{3)^{*}}$ \\ ${ }^{1,2,3}$ Faculty of Economic and Business, University of Jenderal Soedirman
}

\begin{abstract}
This study aims to determine The Influence of Owner Education Levels, Owner Accounting Knowledge, Business Scale, and Business Age on the Use of Accounting Information in MSMEs in Wonogiri Sub-district. The method of data collection conducted in this study is a survey method with a questionnaire. This research was conducted at Regional Wonogiri regency. The dependent variable of this study is owner education levels, owner accounting knowledge, business scale, and business age. The sample in this study amounted to 45 samples and Research is quantitative which uses an analytical approach descriptive. The level of education has a significant influence on the use of accounting information, accounting knowledge has a significant influence on the use of accounting information, business scale does not have a significant influence on the use of accounting information, business age has a significant influence on the use of accounting information, accounting knowledge has the most influence dominant to the use of accounting information in Micro, Small and Medium Enterprises (MSMEs) in Wonogiri District.
\end{abstract}

Keywords: owner education levels, owner accounting knowledge, business scale, business age, and accounting information

\begin{abstract}
ABSTRAK
ni bertujuan untuk mengetahui Pengaruh Tingkat Pendidikan Pemilik, Pengetahuan Akuntansi Pemilik, Skala Bisnis, dan Usia Bisnis terhadap Penggunaan Informasi Akuntansi pada UMKM di Kecamatan Wonogiri. Metode pengumpulan data yang dilakukan dalam penelitian ini adalah metode survei dengan kuesioner. Penelitian ini dilakukan di Kabupaten Wonogiri Regional. Variabel dependen dari penelitian ini adalah tingkat pendidikan pemilik, pengetahuan akuntansi pemilik, skala usaha, dan umur usaha. Sampel dalam penelitian ini berjumlah 45 sampel dan Penelitian ini adalah kuantitatif yang menggunakan pendekatan deskriptif analitis. Tingkat pendidikan mempunyai pengaruh yang signifikan terhadap penggunaan informasi akuntansi, Pengetahuan akuntansi mempunyai pengaruh yang signifikan terhadap penggunaan informasi akuntansi, Skala usaha tidak mempunyai pengaruh yang signifikan terhadap penggunaan informasi akuntansi, Umur usaha mempunyai pengaruh yang signifikan terhadap penggunaan informasi akuntansi, Pengetahuan akuntansi mempunyai pengaruh paling dominan terhadap penggunaan informasi akuntansi pada Usaha Mikro Kecil dan Menengah (UMKM) di Kecamatan Wonogiri.
\end{abstract}

Kata Kunci: tingkat pendidikan pemilik, pengetahuan akuntansi pemilik, skala usaha, umur usaha, dan informasi akuntansi 


\section{INTRODUCTION}

Big companies or industries often regarded as the course of economic development. The development of modern big companies is not the best way for economic development efforts in developing countries, because modern big companies only require a small number of skilled workers and thus fail to overcome the unemployment problem of the many unskilled workforces that are faced.

Development micro, small and medium enterprises (MSMEs) is seen to be able to overcome these weaknesses, in Indonesia. Besides, it also acts as an instrument for job creation, eradicating inequality through a more diverse structure of business ownership, a driver of regional and rural development progress (Febriyanti, 2017). It has been proven so far that small and medium enterprises are an economic sector that helps solve this problem by being able to accommodate a large number of workers, both rural and urban.

The contribution of small and medium micro businesses in Indonesia does not need to be doubted. Since the economic crisis that the Indonesian in 1998, it is evidence that the MSME sector is still able to stand in facing the crisis even today. According to data from the Ministry of Cooperatives and MSMEs, their performance shows developments from 2009-2013. The increasingly existence and performance stretching is not without problems and constraints. The development or development plans that are usually produced by experts or consultants generally come from different cultures or social backgrounds in overcoming important problems (Ketut and Nyoman, 2017).

Accounting information has a very important role in achieving business success, including for small businesses (Pinasti, 2007). Accounting information has an important role to achieve a business success as well as the end result of an accounting process used by various interested parties. Therefore, to be able to encourage small entrepreneurs to organize and use accounting information, it is necessary to start from the knowledge of small entrepreneurs on accounting information. Knowledge of MSME entrepreneurs on accounting information is also determined by their experience in conducting and using accounting information (Linawati, 2015). Accounting users, especially MSME players, should pay more attention to the quality of accounting information on the business they are carrying out by considering the benefits of accounting information that is so great for MSMEs. This is usefulness of accounting information because for decision making (Holmes and Nicholls, 1988).

In Wonogiri there are still many owners or managers of MSMEs who do not understand how to use accounting information, so that they are left behind to take advantage of various government policies that should be an opportunity for them. According to DISPERINDAG of Wonogiri Sub-district, small and medium enterprises have several disadvantages including marketing, human resources, operations, administration and finance. Based on the facts identified, this research is intended to reveal "The Influence of Owner Education Levels, Owner Accounting Knowledge, Business Scale, and Business Age on the Use of Accounting Information in MSMEs in Wonogiri Sub-district"

\section{KAJIAN LITERATUR}

\section{Motivation Theory}

The theory proposed by Bedard and Chi (1993); Spilker (1995), plated that motivation to learn about accounting knowledge will increase the understanding 
of managers or owners in applying accounting in the company. So, it can be concluded that the better the accounting knowledge held by business owners, the better their ability to use accounting information in their business practices (Setyaningrum, Wiratno, and Sukirman, 2014).

\section{Company Theory}

According to Harahap (2007), in line with social progress and increasing public accountability by companies, the theoretical concept of accounting also changes. The company theory in this case states that the company is seen as a social institution operated in order to provide benefits to many interested parties. In this theoretical concept, the center of attention is the whole party or contestant involved or who has interests, both directly and indirectly with the company. Such as owners, management, society, government, creditors, employees and other interested parties. This concept is right applied to companies on a large and modern scale.This is because in terms of accounting, it means that financial reporting responsibilities are not only delivered to shareholders creditors but also to groups or society as a whole.

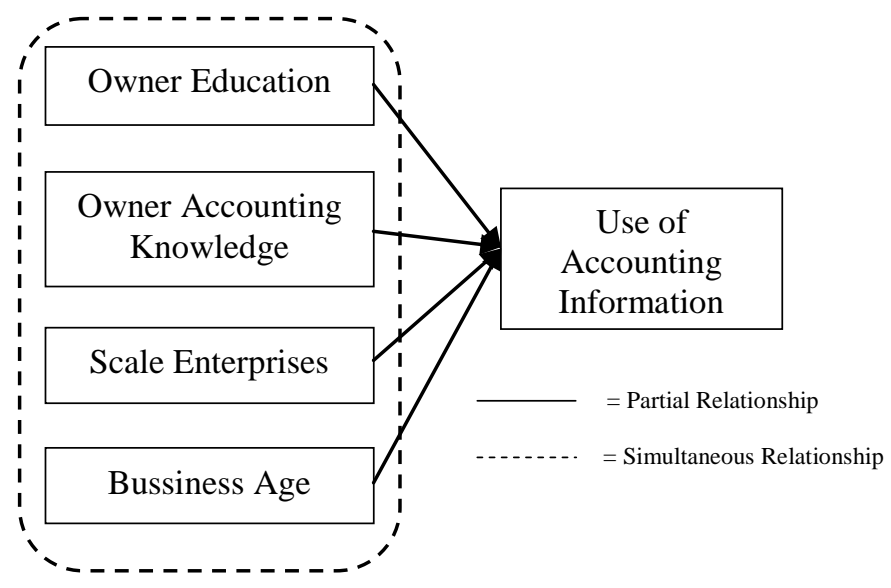

Figure 1. Conceptual Framework

Based on the theoretical foundation described earlier and the recapitulation of the results of previous studies, the research model shown in Figure 1 is proposed this explains the theoretical framework that describes the influence of business scale, education level, accounting knowledge, business age (independent variable) on the preparation and use of accounting information (dependent variable). Then the first hypothesis that can be formulated to be tested in this study is as follows:

\section{H1 : Owner education has a significant effect on the use of accounting information in MSMEs in Wonogiri Sub-district.}

Holmes and Nicholls in (Solovida 2010), suggested that education managers or owners influence the preparation and use of accounting information. Educational programs are alternative activities carried out in order to increase work productivity. With the provision of education, it is expected that every employee is able to understand, interpret and develop his mind logically and rationally, so that the development of human resources through education is expected to help smooth the task for increasing work productivity. Business owners or managers who have a high level of formal education will be better able in using accounting information than those who have a lower formal education level. Then the second hypothesis that can be formulated to be tested in this study is as follows:

\section{H2 : Owner accounting knowledge has a significant effect on the use of accounting information in MSMEs in Wonogiri Sub-district.}

Knowledge of facts includes knowledge of economic events that often occur, knowledge about conversion includes knowledge of financial statements, while knowledge of classification includes journals and ledgers. Accounting knowledge is needed by managers or company owners in carrying out company operations. Motivation to learn about 
accounting knowledge will increase the understanding of managers or owners in its application in the company (Fitriyah, 2006). Leaders need accounting knowledge to produce financial reports that are useful for their users. Then the third hypothesis can be formulated to be tested in this study is as follows:

\section{H3 : Business scale has a significant effect on the use of accounting information in MSMEs in Wonogiri Sub-district.}

Based on the research of Holmes and Nicholls (1989), business scale has a positive effect on the level of use of accounting information. The results of their research stated that the level of accounting information provided depends on the scale of the business, which is measured by the amount of income or sales proceeds and the number of employees. The better the accounting knowledge held by business owners or managers, the better their ability to use accounting information. Along with the development of the company, employees need information to know their rights, climate or atmosphere that occur in the company, social security that can be enjoyed, and so on (Harahap, 2007). Then the fourth hypothesis can be formulated to be tested in this study is as follows:

\section{H4 : Business life significantly influences the use of accounting information in MSMEs in Wonogiri Sub-district.}

Holmes and Nicholls (1989:30) showed that the provision of accounting information is influenced by business age. The results of the study stated that companies that stood for 10 years or less, provide more statutory accounting information, budget accounting information, additional accounting information to be used in decision making, in contrast to companies that stood for 11-20 years. The study also stated that the younger the age of the company there is a tendency to declare extensive accounting information for the purpose of making decisions compared to older companies Growth is influenced significantly by a number of variables including the age of the company (Murniati, 2002). Then the fifth hypothesis can be formulated to be tested in this study is as follows:

\section{H5 : Owner education background is the most significant variable affecting the use of accounting information in MSMEs in Wonogiri Sub-district.}

Among the variables of owner's education owner's accounting knowledge, business scale and business age that most influential to the use of accounting information in a Small and Medium Macro (UMKM) Business is owner education. It is evident of the research conducted by Murniati (2002), which stated that the owners or managers of small and medium enterprises are very dominant in running the company.

\section{RESEARCH METODOLOGY}

This research using quantitative which uses a descriptive-analytical approach, this method provides an overview and presentation of gathered phenomenon or picture of the situation based on existing data. Then proceed by interpreting it as a measure of flow to explain and analyze certain factors on the problem under study. Sugiyono (2016) stated that the survey is a method of collecting primary data directly from the resource persons using a questionnaire.

Objects of this study are MSMEs in Wonogiri Sub-district compristing of the aspect of owner education, owner accounting knowledge, business scale, business age and the use of accounting information. This study will be carried out in the Wonogiri Sub-district, Wonogiri Regency, Central Java.

The data used in this study are primary data obtained from respondents through 
questionnaires. And secondary data obtained by DISPERINDAG.

The population of this study were MSMEs in Wonogiri Sub-district based on DISPERINDAG of Wonogiri Sub-district the number 188 MSMEs that are recorded the size of the population in this research was micro and small entrepreneurs who were conduct in urban wonogiri. The sampling technique for MSMEs was

carried out using purposive sampling method. After this sample criteria were taken, those who fulfilled the requirements amounted to 45 owners of MSMEs in Wonogiri Sub-district.

\section{RESULT AND DISCUSSION \\ Validity Test}

To test validity of the questionnaire, this researh using the product moment correlation formula. The validity analysis of the questionnaire in this research was carried out on the accounting knowledge variable (X2) and the use of accounting information (Y). Referring to the validity test in Appendix 3, a summary of the results can be made in Table 1 and Table 2.

Table 1. Validity Test Result of Accounting Knowledge (X2)

\begin{tabular}{cccc}
\multicolumn{4}{c}{ Table 1. Validity Test Result of Accounting } \\
Knowledge (X2) \\
\hline item & $\mathrm{r}_{\text {statistic }}$ & $\begin{array}{c}\mathrm{r}_{\text {table }} \\
(\text { Sig. } 95 \%)\end{array}$ & Judgement \\
\hline 01 & 0.661 & 0.374 & Valid \\
02 & 0.702 & 0.374 & Valid \\
03 & 0.615 & 0.374 & Valid \\
04 & 0.577 & 0.374 & Valid \\
05 & 0.610 & 0.374 & Valid \\
06 & 0.553 & 0.374 & Valid \\
07 & 0.633 & 0.374 & Valid \\
08 & 0.615 & 0.374 & Valid \\
09 & 0.622 & 0.374 & Valid \\
10 & 0.727 & 0.374 & Valid \\
\hline
\end{tabular}

Source: Processed Primary Data

Table 2. Validity Test Result Use of Accounting

\begin{tabular}{cccc}
\hline item & $\mathrm{r}_{\text {statistic }}$ & $\begin{array}{c}\mathrm{r}_{\text {table }} \\
(\text { Sig. 95 \%) }\end{array}$ & Judgement \\
\hline 01 & 0.783 & 0.374 & Valid \\
02 & 0.728 & 0.374 & Valid \\
03 & 0.835 & 0.374 & Valid \\
04 & 0.808 & 0.374 & Valid \\
05 & 0.763 & 0.374 & Valid \\
06 & 0.719 & 0.374 & Valid \\
07 & 0.818 & 0.374 & Valid \\
08 & 0.773 & 0.374 & Valid \\
09 & 0.837 & 0.374 & Valid \\
10 & 0.750 & 0.374 & Valid \\
\hline
\end{tabular}

\section{Information (Y)}

Source: Processed Primary Data

\section{Reliability Test}

Reliability test used in this research to find out whether measurement already can provide consistency and stability when determined measurement back against the same object.

\section{Table 3.Summary of Questionnaire Reliability Test Results}

\begin{tabular}{crrc}
\hline Variable & $\mathrm{r}_{\text {total }}$ & $\begin{array}{c}\text { Cut of } \\
\text { Value }\end{array}$ & Judgement \\
\hline Accounting Knowledge & 0.783 & 0.374 & Valid \\
Use of Accounting & 0.728 & 0.374 & Valid \\
Information (Y) & 0.835 & 0.374 & Valid \\
\hline
\end{tabular}

Source: Processed Primary Data

Based on the data in Table 3, it can be seen that the reliability coefficient value (rtotal) of the accounting knowledge variable and the accounting information usage variable are each greater than the cut of value (0.600), so all questions for each variable in this study are declared reliable and can be used as data collection tool. 
Table 4. Descriptive analysis Result

\begin{tabular}{|c|c|c|c|c|c|}
\hline Variable & $\mathrm{N}$ & Min & Max & Mean & Dev Std \\
\hline $\begin{array}{l}\text { Owners education } \\
\text { level (X1) }\end{array}$ & 45 & 1.100 & 5.000 & 2.289 & 1.058 \\
\hline $\begin{array}{l}\text { Owners accounting } \\
\text { knowledge (X2) }\end{array}$ & 45 & 2.200 & 4.200 & 3.400 & 0.493 \\
\hline Business scale & 45 & 1.000 & 3.000 & 1.667 & 0.640 \\
\hline Business age (X4) & 45 & 1.000 & 4.000 & 1.844 & 0.767 \\
\hline $\begin{array}{l}\text { Use of accounting } \\
\text { information }(\mathrm{Y})\end{array}$ & 45 & 2.100 & 4.800 & 3.136 & 0.644 \\
\hline
\end{tabular}

Source: Processed Primary Data

On Table 4, shows that the accounting knowledge variable data has the highest minimum value, while the education level, business scale and business age variable data data each have the lowest minimum value. The highest maximum value is the education level variable data, while the business scale variable data has the lowest maximum value.

\section{Normality Test}

This test is used to find out whether the regression in this research that show relationship between dependent variable and the independent variables are both normally distributed or not in the analysis of graphs and statistical tests.

Table 5. Normality Test Result

\begin{tabular}{cccc}
\hline Variable & $\begin{array}{c}\text { Kolmogorov } \\
\text {-Smirnov }\end{array}$ & Sig. & Judgement \\
\hline $\begin{array}{c}\text { Standardized } \\
\text { Residual }\end{array}$ & 0.550 & 0.923 & $\begin{array}{c}\text { Normal } \\
\text { Distribution }\end{array}$ \\
\hline
\end{tabular}

Source: Processed Primary Data

Based on the output of the normality test data in Appendix 7, it can be seen that the asymp value. sig. (2-tailed) from the Kolmogorov-Smirnov $\mathrm{Z}$ test for standardized residual variables is 0.923 greater than value of 0.05 . it can be concluded that the data used is normally distributed. The summary of the results of the normality test can be seen in Table 5 .
Table 6. Summary of Multicollinearity Test Results

\begin{tabular}{lrc}
\hline \multicolumn{1}{c}{ Variable } & V IF & Jugement \\
\hline Owners education level (X1) & 0.687 & No Multicollinearity \\
Owners accounting & 1.667 & No Multicollinearity \\
knowledge (X2) & & \\
Business scale (X3) & 1.065 & No Multicollinearity \\
Business age (X4) & 1.081 & No Multicollinearity \\
Source: Processed Primary Data &
\end{tabular}

Variance Inflation Factor (VIF) test output in Appendix 7 shows that the VIF valueof education level variable (X1), accounting knowledge (X2), business scale (X3) and VIF value of business age variable (X4) are each smaller than 10 so It can be concluded that there is no multicollinearity in the regression model. A summary of the results of the multicollinearity test can be seen in Table 6.

\section{Heteroscedasticity Test}

Heterocedasticity used to find out whether in regression models of variance inequality is occurred from residual one other observation to observation. If the variance remains then it is called homocedasticity and if different then heterocedasticity problem occurs. Good regression models are homocedasticity or heterocedasticity does not occur.

\section{Table 7. Summary of Multicollinearity Test} Results

\begin{tabular}{lcc}
\hline \multicolumn{1}{c}{ Variable } & VIF & Jugement \\
\hline $\begin{array}{l}\text { Owners education level } \\
\text { (X1) }\end{array}$ & 0.233 & No Heteroscedasticity \\
$\begin{array}{l}\text { Owners accounting } \\
\text { knowledge (X2) }\end{array}$ & 0.136 & No Heteroscedasticity \\
Business scale (X3) & 0.228 & No Heteroscedasticity \\
Business age (X4) & 0.386 & No Heteroscedasticity \\
\hline SOurce: Processed Primary & Data
\end{tabular}

Source: Processed Primary Data

Based on the output of the heteroscedasticity test using Glesjer test, the significance value of the $t$ level 
education variable (X1), accounting knowledge variable (X2), business scale (X3) and the $t$ test significance of the business age variable (X4) are greater than the value (0.05). Based on this evidence, it can be concluded that there is no heteroscedasticity in the regression model. The summary of the results of the hyroscedasticity test can be seen in Table 7.

\section{Multiple Regression Analysis}

Multiple linear regression use in this research to measure the influence between more than one variable (the independent variable) on variable (the dependent variable).

Table 8. Descriptive analysis Result

\begin{tabular}{lccc}
\hline \multicolumn{1}{c}{ Variable } & $\begin{array}{c}\text { Coefficient } \\
\text { Regression }\end{array}$ & $\mathrm{T}_{\text {statistic }}$ & (two tailed) \\
\hline $\begin{array}{l}\text { Owners education } \\
\text { level (X1) }\end{array}$ & 0.209 & 2.378 & 2.021 \\
Owners accounting & 0.514 & 2.738 & 2.021 \\
knowledge (X2) & & & \\
Business scale (X3) & 0.091 & 0.788 & 2.021 \\
Business age (X4) & 0.209 & 2.156 & 2.021 \\
\hline Constanta & 0.372 & & \\
Coef. Determination & 0.505 & & \\
F & 10.184 & & \\
\hline Statistic &
\end{tabular}

Source: Processed Primary Data

Based on the data in Table 4.8, then multiple regression equations can be made as follows:

$\mathrm{Y}=0,372+0,209 \mathrm{X} 1+0,514 \mathrm{X} 2+0,091 \mathrm{X} 3+0,209 \mathrm{X} 4$

\section{Hypothesis Testing}

\section{a. First hypothesis}

Based on the results of the $t$ test of multiple regression analysis, the $\mathrm{t}$-count level of education variable (2.378) is greater than the value of $t$ table (2.021). The results of these statistical tests show evidence that partially the level of education has a positive and significant influence on the use of accounting information. Thus, the first hypothesis which states that the level of education has a significant influence on the use of accounting information in Micro, Small and Medium Enterprises (MSMEs) in Wonogiri District, is accepted.

\section{b. Second hypothesis}

Referring to the results of the $t$ test of multiple regression analysis, it can be seen that the value of $t$ count accounting knowledge variable (2.738) is also greater than the value of $t$ table (2.021). The test results prove that accounting knowledge has a positive and significant effect on the use of accounting information. Thus, the second hypothesis which states that accounting knowledge has a significant influence on the use of accounting information in Micro, Small and Medium Enterprises (MSMEs) in Wonogiri District, is accepted.

\section{c. Third hypothesis}

The t-test output from multiple regression analysis shows that the t-count of the business scale variable (0.788) is smaller than the t-table value (2.021). The results of these statistical tests show that partially the business scale variable has a positive but not significant effect on the use of accounting information, therefore the third hypothesis is rejected.

\section{d. Fourth hyphothesis}

Furthermore, the t-test output from multiple regression analysis shows that the $\mathrm{t}$ - count of the business age variable (2.156) is greater than the value of t table (2.021). The test results show evidence that the business age has a positive and significant influence on the use of accounting information. Thus, the fourth hypothesis which states that business age has a significant influence on the use of accounting information in Micro, Small and Medium Enterprises (MSMEs) in Wonogiri District, is accepted. 


\section{e. Fifth hyphothesis}

The results of the test show that accounting knowledge has the greatest influence on the use of accounting information when compared with the level of education, business scale and business age variables. Thus, the fifth hypothesis which states that the level of education has the most dominant influence on the use of accounting information in Micro, Small and Medium Enterprises (MSMEs) in Wonogiri District, is rejected.

\section{Discussion of Result}

1. The level of education has a significant Wonogiri Subdistrict must also be able to influence on the use of accounting information maintain and develop their business amid in Micro, Small and Medium Enterprises increasingly competitive conditions.

(MSMEs) in Wonogiri District.

2. Accounting knowledge has a significant REFERENCES influence on the use of accounting information Bedard, Jean C., and M. C. Chi. 1993. in Micro, Small and Medium Enterprises (MSMEs) in Wonogiri District.

3. Business scale does not have a significant effect on the use of accounting information in Febriyanti, Tri Ariska. 2017. "Pengaruh Micro, Small and Medium Enterprises (MSMEs) in Wonogiri District.

4. Business life has a significant influence on the use of accounting information in Micro, Small and Medium Enterprises (MSMEs) in Fitriyah, Hadiyah. 2006. "Analisis FaktorWonogiri District.

5. Accounting knowledge has the most dominant influence on the use of accounting information in Micro, Small and Medium Enterprises (MSMEs) in Wonogiri District.

\section{CONCLUSION}

This research show that education of MSME owners, accounting knowledge held by MSMEs owners, Business age affects the use of accounting information. Meanwhile, business scale that does not affect the use of accounting information. Among all independent variable, accounting knowledge has the most dominant influence on the use of accounting information on MSMEs.

In an effort to continue to increase the use of accounting information, the owners of Micro, Small and Medium
"Expertise in Auditing." Auditing: Journal of Pratcise and Theory Vol. 12.

Tingkat Pendidikan Pemilik, Skala Usaha, Umur Usaha Terhadap Pemanfaatan Informasi Keuangan." Universitas Jember.

Faktor Yang Mempengaruhi Penggunaan Informasi Akuntansi Pada Usaha Kecil Menengah Kabupaten Sidoharjo." UNAIR: Surabaya.

Harahap, Sofyan safri. 2007. Teori Akuntansi. Revised. Jakarta: Raja Grafindo Pustaka.

Holmes, Scott, and Des Nicholls. 1988. "An Analysis of the Use of Accounting By Australian Small Business An Analysis of the Use of Accounting By Australian Small Business." Journal of Small Business Management.

Holmes, Scott, and Des Nicholls. 1989. "Modelling The Accounting Information Requirement of Small Business." Accounting and Business Research 19(74).

Ketut, Yasa, and Trisna Nyoman. 2017. 
"Pengaruh Skala Usaha, Umur

Perusahaan, Pengetahuan Dan

Akuntansi Terhadap Penggunaan

Informasi Akuntansi Pada Usaha Kecil

Menengah Di Kecamatan Buleleng

Dengan Ketidakpastian Lingkungan

Sebagai Variable Pemoderasi."

Universitas Pendidikan Ganesha 8(2).

Linawati, Evi. 2015. "Pengetahuan

Akuntansi Perilaku Usaha Mikro Kecil

Dan Menengah (UMKM) Atas

Penggunaan Informasi Akuntansi.

Universitas UNISSULA." Universitas

UNISSULA 2(1).

Murniati. 2002. "Analisis Faktor-Faktor

Yang Mempengaruhi Penyiapan Dan

Penggunaan Informasi Akuntansi Pada

Pengusaha Kecil Dan Menengah Di

Jawa Tengah." Universitas

Diponegoro.

Pinasti, Margani. 2007. "Pengaruh

Penyelenggaraan Dan Penggunaan

Informasi Akuntansi Terhadap

Persepsi Pengusaha Kecil Atas

Informasi Akuntansi." Jurnal Riset

Akuntansi Indonesia 10(3).

Setyaningrum, Destiana, Adi Wiratno, and

Sukirman. 2014. "Pengaruh

Pendidikan Pemilik, Pengetahuan

Akuntansi Pemilik, Budaya

Perusahaan, Dan Umur Usaha

Terhadap Penggunaan Informasi

Akuntansi Pada UKM Dengan

Ketidakpastian Lingkungan."

Universitas Jenderal Soedirman.

Solovida, Grace Tianna. 2010. "Faktor-

Faktor Yang Mempengaruhi

Penyiapan Dan Penggunaan Informasi

Akuntansi Pada Perusahaan Kecil Dan

Menengah Di Jawa Tengah." 6(1).

Spilker, C. 1995. "The Effects of Time

Pressure and Knowledge on Key Word

Selection Behavior in Tax Research."

The Accounting Review 70(1):49-70.

Sugiyono. 2016. Metode Penelitian

Kuantitatif, Kualitatif Dan $R \& D$.

Bandung: Alfabeta. 